\title{
Phosphorus Speciation in Atmospherically Deposited Particulate Matter and Implications for Terrestrial Ecosystem Productivity
}

Peggy A. O'Day ${ }^{\mathrm{a},{ }^{*}+},{ }^{\ddagger}$, Ugwumsinachi G. Nwosu $^{\mathrm{a}, \ddagger}$, Morgan E. Barnes ${ }^{\mathrm{b}}$, Stephen C. Hart ${ }^{\mathrm{a}}$, Asmeret Asefaw Berhe ${ }^{\mathrm{a}}$, John N. Christensen ${ }^{\mathrm{c}}$, and Kenneth H. Williams ${ }^{\mathrm{c}, \mathrm{d}}$

${ }^{a}$ Life and Environmental Sciences Department, and the Sierra Nevada Research Institute, University of California, Merced, CA 95343

${ }^{\mathrm{b}}$ Environmental Systems Graduate Group, University of California, Merced, CA 95343

${ }^{\mathrm{c}}$ Earth and Environmental Sciences, Lawrence Berkeley National Laboratory, Berkeley, CA 94720

${ }^{\mathrm{d}}$ Rocky Mountain Biological Lab, Gothic, CO 81225

* correspondence to: poday@ucmerced.edu

These authors contributed equally

\section{Supporting Information:}

Pages: 22

Supplementary text: DETAILED MATERIALS AND METHODS

Figures $\mathrm{S} 1$ to $\mathrm{S} 9$

Tables S1 to S4

SI References 


\section{DETAILED MATERIALS AND METHODS}

\section{Sample Collection}

Airborne particulate matter (PM) was collected at the East River Watershed, Colorado (COERW) and the California Southern Sierra Critical Zone Observatory (CA-SSCZO; Fig. S1). Locations and sample collection dates are shown in Table S1. Two high elevation sites at COERW (LS and PH) were sampled by dry deposition (Sept.-Oct. 2016) and by snow sampling (winter, 2017). At the CA-SSCZO, the high elevation site ( $\mathrm{SH}$ ) was sampled twice by dry deposition (Sept.-Nov. 2016; July-Sept. 2017) and once by snow sampling (winter, 2017). The low elevation site CA-SSCZO (SJ) was below the snow line and was sampled three times by dry deposition (Table S1). Sample collection methods for dry deposition were previously employed by Aciego et al. ${ }^{1}$ and used acid-cleaned passive collectors $(25.4 \mathrm{~cm}$ diameter Teflon-coated pans) filled with quartz beads on top of a Teflon or polypropylene mesh at the base of the pan. Bird repellent and netting was used to protect from contamination. Multiple collectors (six collectors per site) were deployed on two-meter high wooden poles at each site for 1-2 months. Pans were retrieved, washed with deionized (DI) water, and filtered in series with multiple $10 \mu \mathrm{m}$ (PM $\geq 10$ $\mu \mathrm{m})$ and $1 \mu \mathrm{m}$ (PM 1-10 $\mu \mathrm{m}$ ) PTFE filters (for one sample, SJ1, $0.2 \mu \mathrm{m}$ filters were used instead of $1 \mu \mathrm{m}$ filter). Both individual and composited filters were analyzed, depending on the type of measurement.

Snow samples were collected at the three high elevation sites in spring or summer 2017 to capture PM deposition over the winter (Table S1). At the CO-ERW sites, snow samples were collected over the upper $10 \mathrm{~cm}$ of a $1 \mathrm{~m}^{2}$ snow field surface having visible accumulation of an outcropping dust layer, with the melted snow water then homogenized. At the high elevation CA-SSCZO site, a profile area $(65 \times 43 \mathrm{~cm})$ was collected over a total snow depth of $134 \mathrm{~cm}$. Samples were collected in approximately $20 \mathrm{~cm}$ increments with depth. The bottom $10 \mathrm{~cm}$ at the soil-snow interface were not collected to prevent contamination from the soil surface. A total of six layers were collected; this study focused on a sample (SH2) collected from the uppermost layer $(0-20 \mathrm{~cm})$. 


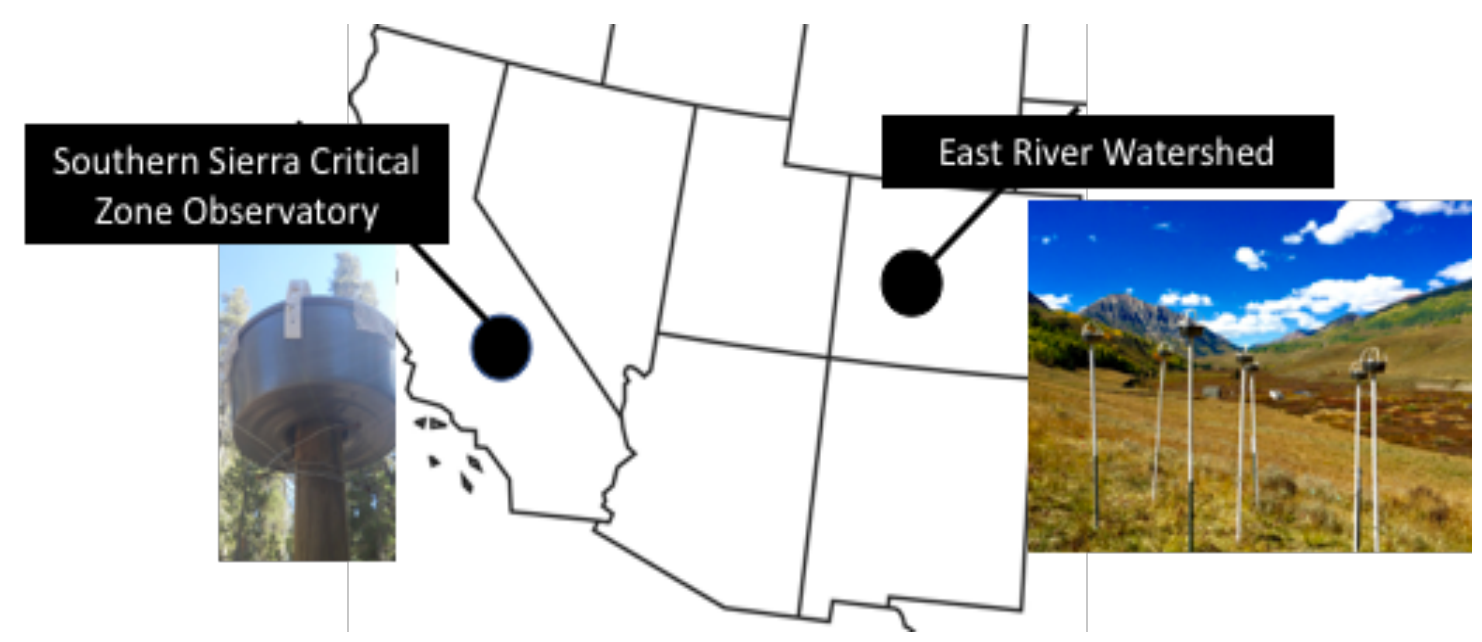

Figure S1. Location of study sites in Colorado and California for airborne particulate matter collection. Inset photos show passive samplers for dry deposition collection.

Table S1. Summary of particulate matter sample locations and sampling periods for this study.

\begin{tabular}{|c|c|c|c|c|}
\hline Name & $\begin{array}{l}\text { Sample } \\
\text { Type }\end{array}$ & $\begin{array}{l}\text { Elevation } \\
\text { (m) }\end{array}$ & Location & Collection Period \\
\hline \multicolumn{5}{|c|}{ East River Watershed (ERW), Colorado } \\
\hline LS1 & Dry & 3100 & $38^{\circ} 57^{\prime} 23.2^{\prime \prime} \mathrm{N}, 107^{\circ} 01^{\prime} 43.9^{\prime \prime} \mathrm{W}$ & $09 / 17 / 16-10 / 30 / 16$ \\
\hline LS2 & Snow & 3100 & $38^{\circ} 57^{\prime} 23.2^{\prime \prime} \mathrm{N}, 107^{\circ} 01^{\prime} 43.9^{\prime \prime} \mathrm{W}$ & $07 / 10 / 17$ \\
\hline $\mathrm{PH} 1$ & Dry & 2800 & $38^{\circ} 55^{\prime} 13.2^{\prime \prime} \mathrm{N}, 106^{\circ} 56^{\prime} 57.0^{\prime \prime} \mathrm{W}$ & $09 / 17 / 16-10 / 30 / 16$ \\
\hline $\mathrm{PH} 2$ & Snow & 2800 & $38^{\circ} 55^{\prime} 13.2^{\prime \prime} \mathrm{N}, 106^{\circ} 56^{\prime} 57.0 " \mathrm{~W}$ & $04 / 17 / 17$ \\
\hline \multicolumn{5}{|c|}{ Southern Sierra Critical Zone Observatory (SSCZO), California } \\
\hline $\mathrm{SH} 1$ & Dry & 2700 & $37^{\circ} 04^{\prime} 01.4^{\prime \prime N}, 118^{\circ} 59^{\prime} 13.9^{\prime \prime W}$ & $09 / 02 / 16-11 / 06 / 16$ \\
\hline $\mathrm{SH} 2$ & Snow & 2500 & $37^{\circ} 01^{\prime} 31.2^{\prime \prime} \mathrm{N}, 118^{\circ} 59^{\prime} 48.4^{\prime \prime W}$ & $04 / 30 / 17$ \\
\hline $\mathrm{SH} 3$ & Dry & 2700 & $37^{\circ} 04^{\prime} 01.4^{\prime \prime} \mathrm{N}, 118^{\circ} 59^{\prime} 13.9^{\prime \prime} \mathrm{W}$ & $07 / 03 / 17-09 / 03 / 17$ \\
\hline SJ1 & Dry & 400 & $37^{\circ} 06^{\prime} 28.7^{\prime \prime} \mathrm{N}, 119^{\circ} 43^{\prime} 54.8^{\prime \prime} \mathrm{W}$ & $09 / 02 / 16-10 / 13 / 16$ \\
\hline SJ2 & Dry & 400 & $37^{\circ} 06^{\prime} 15.2^{\prime \prime} \mathrm{N}, 119^{\circ} 43^{\prime} 15.8^{\prime \prime} \mathrm{W}$ & $06 / 15 / 17-07 / 21 / 17$ \\
\hline SJ3 & Dry & 400 & $37^{\circ} 06^{\prime} 15.2^{\prime \prime} \mathrm{N}, 119^{\circ} 43^{\prime} 15.8^{\prime \prime} \mathrm{W}$ & $08 / 03 / 17-08 / 31 / 17$ \\
\hline
\end{tabular}




\section{Elemental Analysis}

All laboratory procedures used ultrapure water $(18.2 \mathrm{M} \Omega \cdot \mathrm{cm}$, EASYpure UV, Barnstead

Thermolyne). Elemental sample composition was determined by acid digestion of PM samples and analysis using ICP-OES. Samples were digested using microwave acid digestion (Anton Paar Multiwave 3000) with aqua regia (9 $\mathrm{mL} \mathrm{HCl}$ and $3 \mathrm{~mL} \mathrm{HNO}_{3}$ to $10-20 \mathrm{mg}$ of dried sample). Digests were diluted with ultrapure water to $4 \%$ nitric acid prior to analysis. Samples were measured for total P, Ca, Mg, K, Al, and Fe by ICP-OES (PerkinElmer Optima 5300 DV). Acid blanks and standards of known concentrations were run repeatedly to ensure accuracy and reproducibility. Instrumental error was $\leq 3 \%$. For total $\mathrm{P}$, the instrumental detection limit was 10 ppb. Results of bulk PM sample analyses are shown in Fig. S2 and S3.

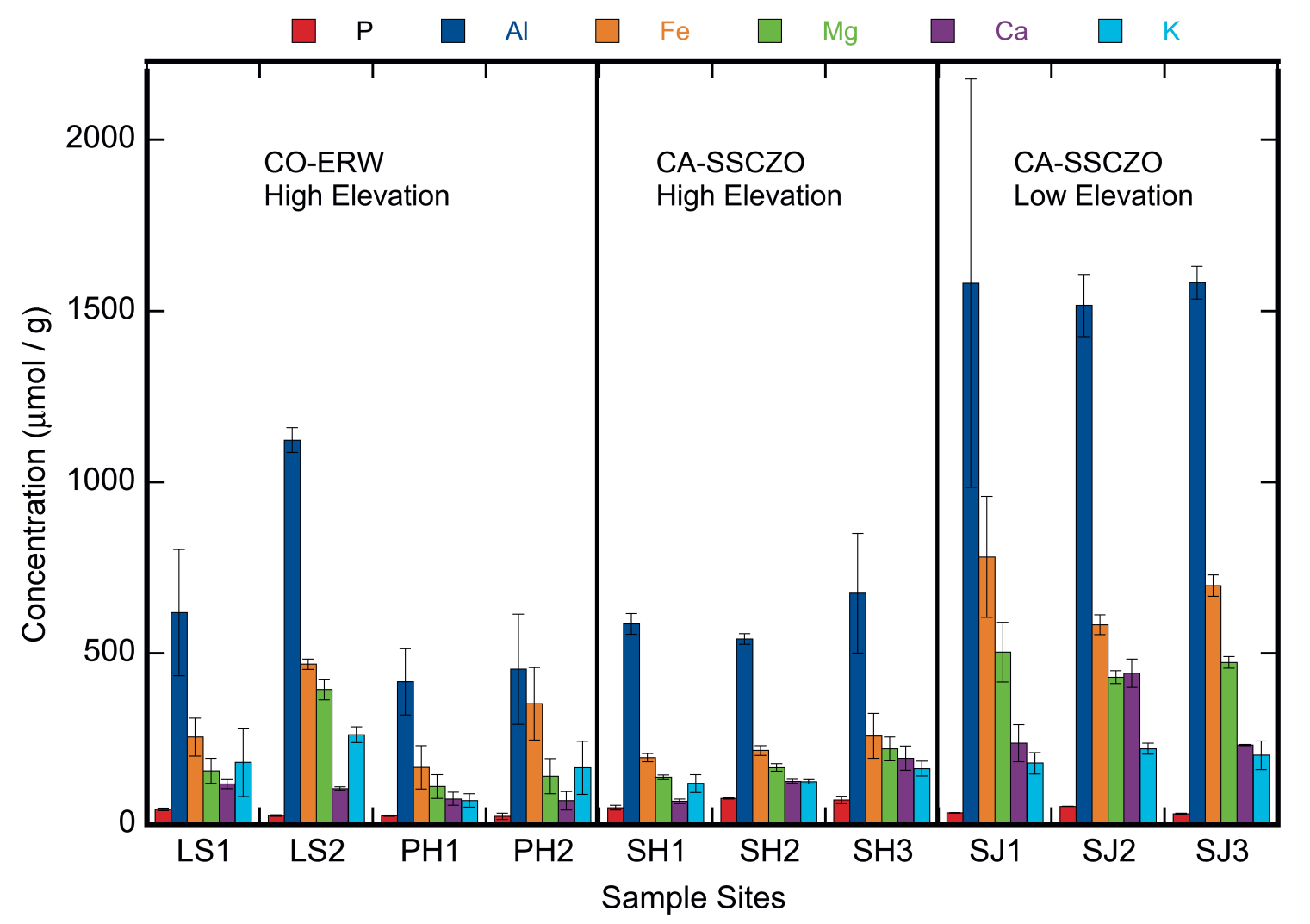

Figure S2. Elemental analysis of bulk PM samples from the Colorado East River Watershed, (CO-ERW) (LS1, LS2, PH1, PH2 ) the California Southern Sierra Critical Zone Observatory (CA-SSCZO) with high (SH1, SH2, SH3) and low (SJ1, SJ2, SJ3) elevation sites. Error bars are standard deviations of replicate analyses of different filter samples ( $n=3$ to 6 ). 


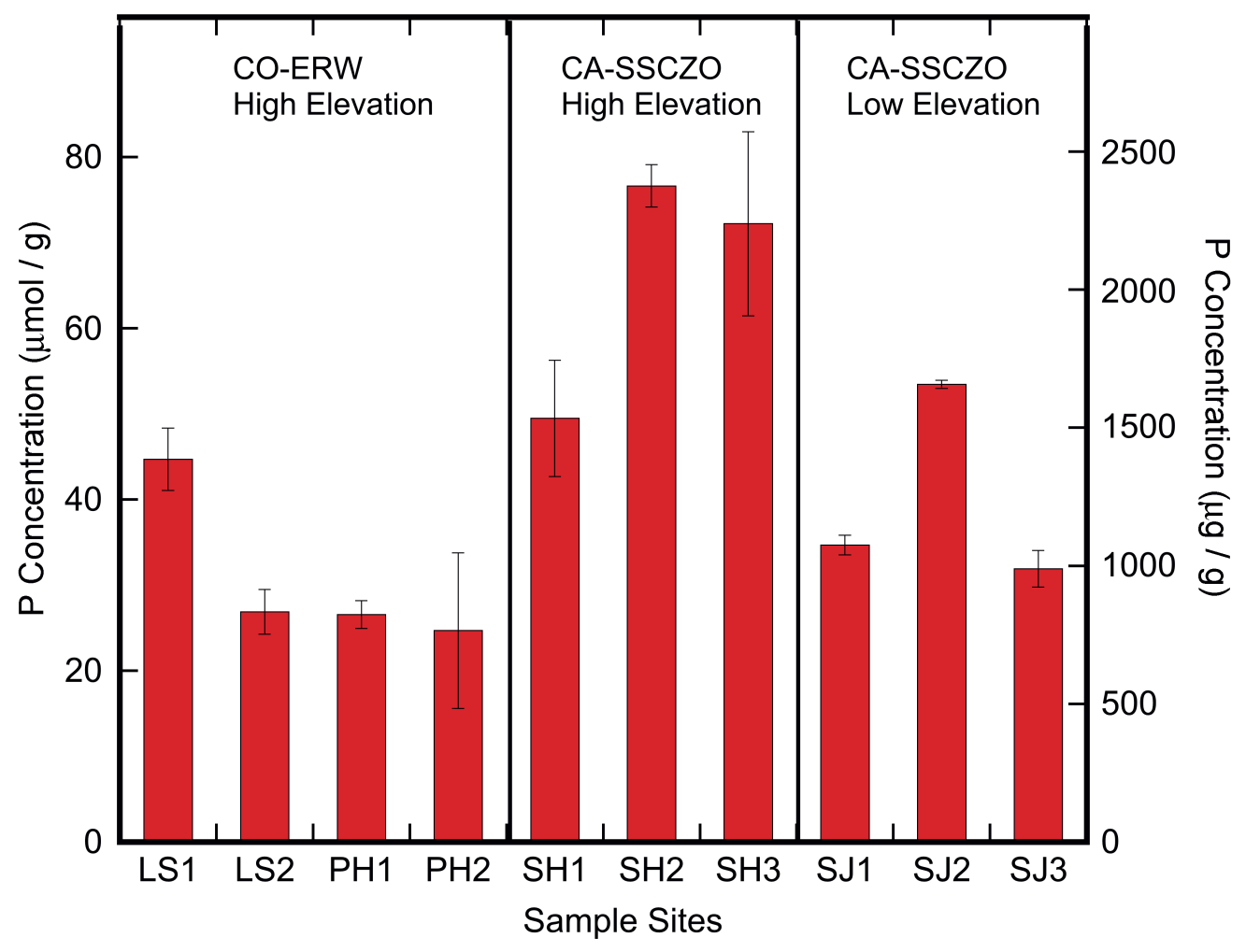

Figure S3. Total P concentrations (expanded from Fig. S2) in bulk PM samples from the Colorado East River Watershed, (CO-ERW) (LS1, LS2, PH1, PH2) the California Southern Sierra Critical Zone Observatory (CA-SSCZO) with high (SH1, SH2, SH3) and low (SJ1, SJ2, SJ3) elevation sites. Error bars are standard deviations of replicate analyses of different filter samples ( $n=3$ to 5$)$. 


\section{Phosphorus K-edge X-ray Absorption Spectroscopy (XAS)}

\section{Phosphorus Reference Compounds}

Phosphorus compounds were obtained from Sigma Aldrich (reagent grade or better). Phytate compounds (Al-, Ca-, and Fe-phytate) were synthesized in the laboratory according to a published method. ${ }^{2}$ Gibbsite $\left(\mathrm{Al}(\mathrm{OH})_{3}\right)$ was obtained from Huber Engineered Materials (Micral 916). Ferrihydrite (amorphous $\left.\mathrm{Fe}(\mathrm{OH})_{3}\right)$ and goethite $(\mathrm{FeOOH})$ were synthesized in the laboratory following published methods. ${ }^{3}$ Reference standards of dissolved orthophosphate or inositol hexakisphosphate (IHP) adsorbed on ferrihydrite, goethite, or gibbsite were prepared by shaking $30 \mathrm{ml}$ of $2 \mathrm{mM}$ of $\mathrm{KH}_{2} \mathrm{PO}_{4}$ or IHP solution in $0.01 \mathrm{KCl}$ with $100 \mathrm{mg}$ of adsorbent material for $18 \mathrm{~h}$ ( $\mathrm{pH} \sim 6$ ). For DNA adsorption on gibbsite, $\sim 100 \mathrm{mg}$ DNA was used in $30 \mathrm{ml}$ of DI water. After the reaction period, suspensions were centrifuged at $16,500 \mathrm{rpm}$, supernatant solutions removed, and solid material dried at $45^{\circ} \mathrm{C}$ for 3 days, except for orthophosphate adsorbed on ferrihydrite and goethite reference standards, which were air dried for 4 days.

\section{Bulk K-Edge Absorption Near-edge Structure (XANES) Spectroscopy}

Bulk K-edge P-XANES were collected at beamline 14-3 at the Stanford Synchrotron Radiation Lightsource (SSRL), Stanford, CA and at the soft X-ray micro-characterization beamline (SXRMB) at the Canadian Light Source (CLS), Saskatoon, Canada. Sample spectra were collected by mounting PM filters directly on P-free, double-sided carbon tape. Reference compounds were diluted with either sucrose or boron nitride $(\mathrm{BN})$ and mounted on sample holders with P-free, double-sided carbon tape. Reference compound spectra were monitored for self-absorption; fluorescence spectra for a few compounds were compared with spectra collected using a total electron yield (TEY) detector to verify no significant self-absorption in the fluorescence signal. All spectra were collected at room temperature. At SSRL, storage ring energy was $3 \mathrm{GeV}$ and beam current was $500 \mathrm{~mA}$. Beamline 14-3 was equipped with a watercooled $\mathrm{Si}(111)$ double-crystal monochromator (theta $=90^{\circ} \mathrm{cut}$ ) and beamline energy resolution was $\sim 1 \times 10^{-4} \mathrm{eV}$. Samples were maintained in a He gas environment during data collection. XANES data were collected in fluorescence mode with a Vortex 4-channel Si drift detector. The storage ring at CLS was $2.9 \mathrm{GeV}$ with maximum beam current of $250 \mathrm{~mA}$. The SXRMB beamline was equipped with a $\mathrm{Si}(111)$ double-crystal monochromator. Samples were maintained in vacuum during data collection. Energy was calibrated at the $\mathrm{P}$ K-edge using either a $\mathrm{NaH}_{2} \mathrm{PO}_{4}$ 
standard, for which peak maximum absorption was set to $2152.6 \mathrm{eV}$, or tetraphenylphosphonium bromide $\left(\mathrm{PPh}_{4} \mathrm{Br}\right)$, with the first peak maximum set to $2146.96 \mathrm{eV}$. Lecithin was used as a secondary standard for energy calibration. Standard spectra were collected for each run and cross-calibrated between different beamlines and runs. At least four scans were collected for $\mathrm{P}$ reference standards and 8-16 scans for PM samples, and no changes in spectral features were observed in successive scans. XANES spectra were averaged and processed using Sam's Interface for XAS Package (SIXPACK). ${ }^{4}$ Data processing and analyses were done with the ATHENA software package. (Demeter 0.9.20). ${ }^{5}$ All of the P reference spectra shown in Fig. S4 were tested in linear combination (LC) fits. Fits were performed with the component sum not forced to unity and only fits within $100 \pm 2.5 \%$ were accepted. A series of sensitivity tests were performed by fitting linear combinations of one to four reference compound spectra and ranking

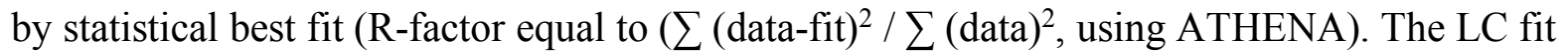
with the highest rank using the fewest number of components, and with a component total of 100 $\pm 2.5 \%$, was selected as the best fit. Additional sensitivity tests were performed with spectra of the same reference compound collected at different times, and by comparing results between smoothed and unsmoothed spectra. Statistical uncertainties of individual fractions in LC best fits varied from $1.5-2.5 \%$. Numerical results are given in Table S2.

\section{Microfocused ( $\mu$-) X-ray Fluorescence $(X R F)$ and XANES}

Microfocused synchrotron X-ray data were collected at both beamline 14-3 at SSRL and SXRMB at CLS under ring and beamline conditions given above. Particles spread on tape or filters were mapped at the P K-edge by $\mu$-XRF with an $\sim 10 \mu \mathrm{m}$ beam spot and $\mu$-XANES spectra were collected on high count spots. Spot scans were averaged, processed, and analyzed by LC fits in the same manner as described above for bulk sample spectra. Data were analyzed using Sam's Microprobe Analysis Kit (SMAK). 
A. Organic $P$

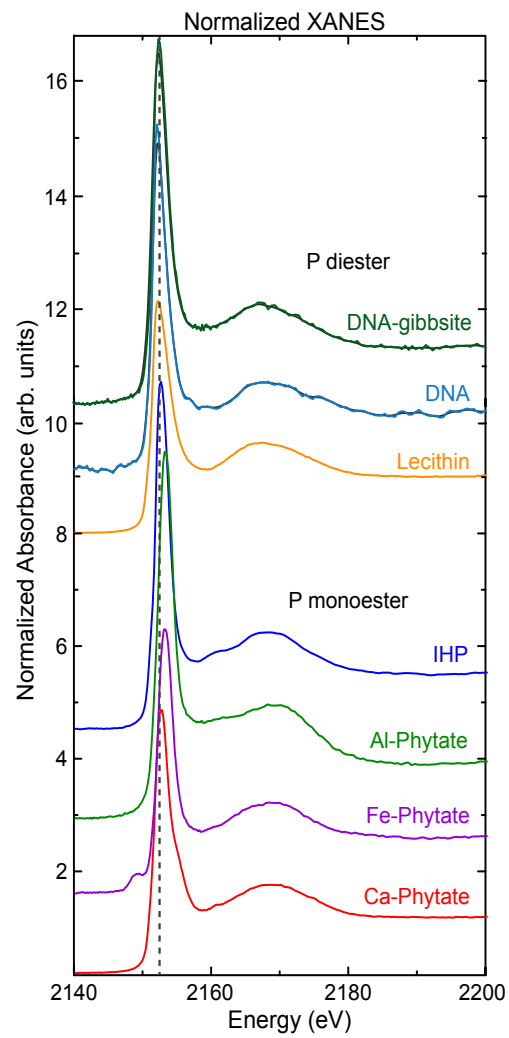

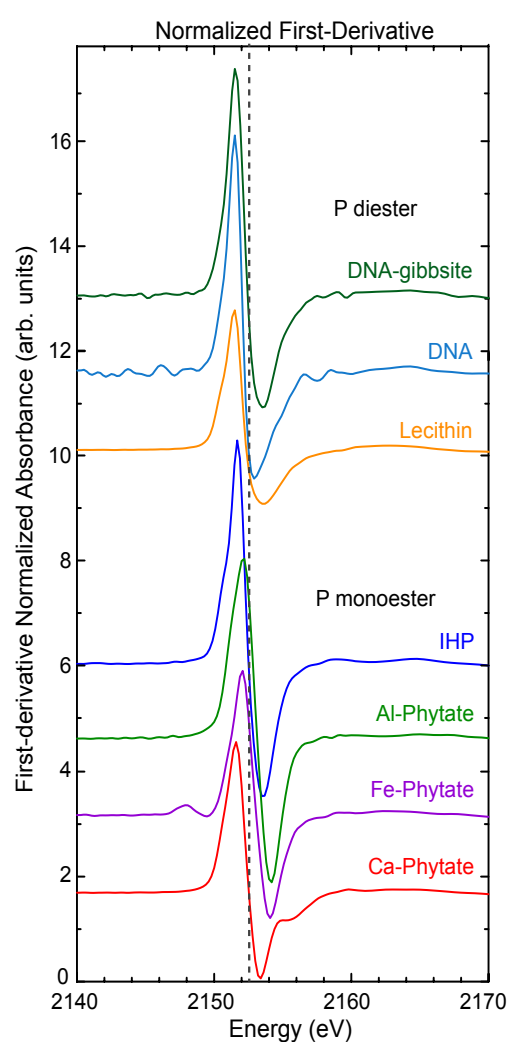

B. Inorganic $P$

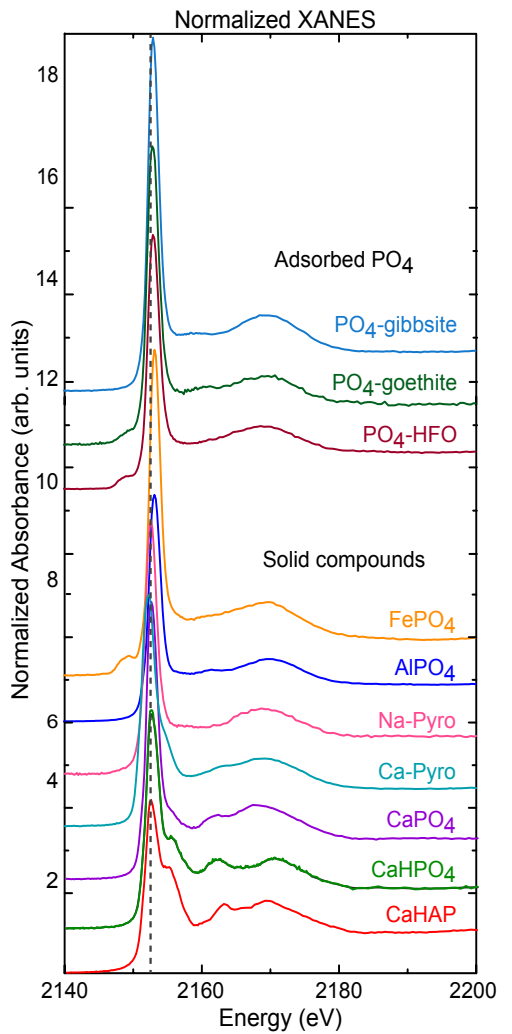

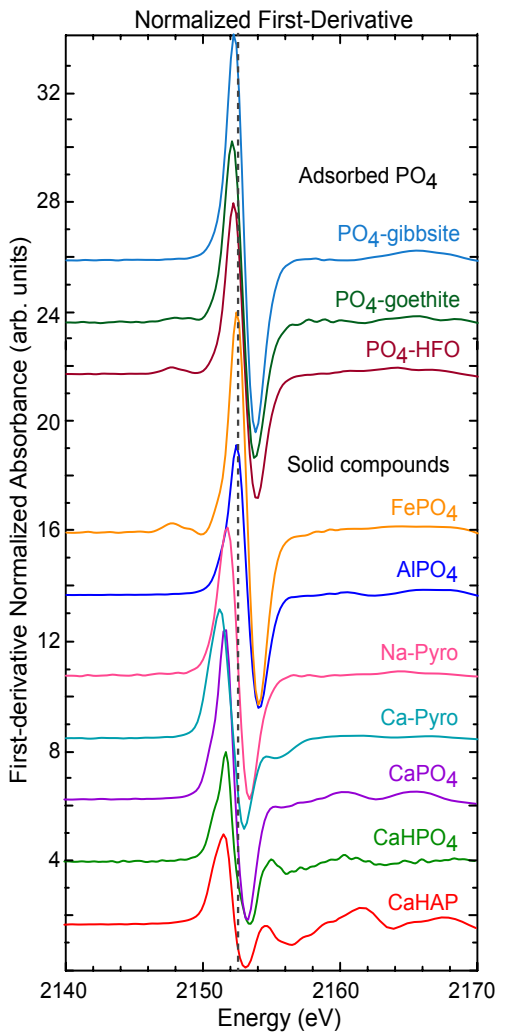

Figure S4. Phosphorus K-edge normalized and first-derivative XANES reference spectra. A. Organic $P$ compounds and adsorbed species: Orthophosphate monoester (P-monoester) spectra - Ca-phytate, Fe-phytate, Al-phytate, and IHP (inositol hexakisphosphate, $\mathrm{Na}$ salt); orthophosphate diester (P-diester) spectra - Lecithin $\left(\mathrm{C}_{35} \mathrm{H}_{66} \mathrm{NO}_{7} \mathrm{P}\right)$, DNA (deoxyribonucleic acid), and DNA adsorbed on gibbsite (DNA-gibbsite). B. Inorganic orthophosphate compounds and adsorbed orthophosphate species $\left(\mathrm{PO}_{4}\right)$ : Ca hydroxyapatite (Ca HAP), Ca hydrogen phosphate $\left(\mathrm{CaHPO}_{4}\right), \mathrm{AlPO}_{4}$, and $\mathrm{FePO}_{4} ; \mathrm{PO}_{4}$ adsorbed on: hydrous ferric oxide $\left(\mathrm{PO}_{4}-\mathrm{HFO}\right)$; goethite $\left(\mathrm{FeOOH} ; \mathrm{PO}_{4}\right.$-goethite), and gibbsite $\left(\mathrm{Al}(\mathrm{OH})_{3} ; \mathrm{PO}_{4}\right.$-gibbsite). Vertical dashed line indicates energy calibration using $\mathrm{NaH}_{2} \mathrm{PO}_{4}$ standard with peak maximum set to $2152.6 \mathrm{eV}$. 


\section{Analysis of Reference XANES Spectra}

Reference standards used for P K-edge XAS are shown in Fig. S4. Although P XANES reference spectra have generally similar features, differences in the energy and width of the sharp absorption maximum (2151.8-2153.5 eV), and in the shape and position of absorption features in the pre-edge (2148.5-2150.5 eV) and post-edge regions (2158-2170 eV), enable differentiation of different classes of compounds. Metal cations (particularly $\mathrm{Ca}^{2+}, \mathrm{Al}^{3+}$, or $\mathrm{Fe}^{3+}$ ) have different electron-withdrawing affinities for $\mathrm{O}$ ligands that bridge between $\mathrm{P}$ and the metal cation, which imparts a slightly different energy shift to the maximum absorption peak. In addition, differences in pre-edge (for $\mathrm{Fe}^{3+}$ ) and post-edge (for $\mathrm{Al}^{3+}$ and $\mathrm{Ca}^{2+}$ ) absorption features (Figs. S4 and S5) are distinctive, as others have found ${ }^{6,7}$.
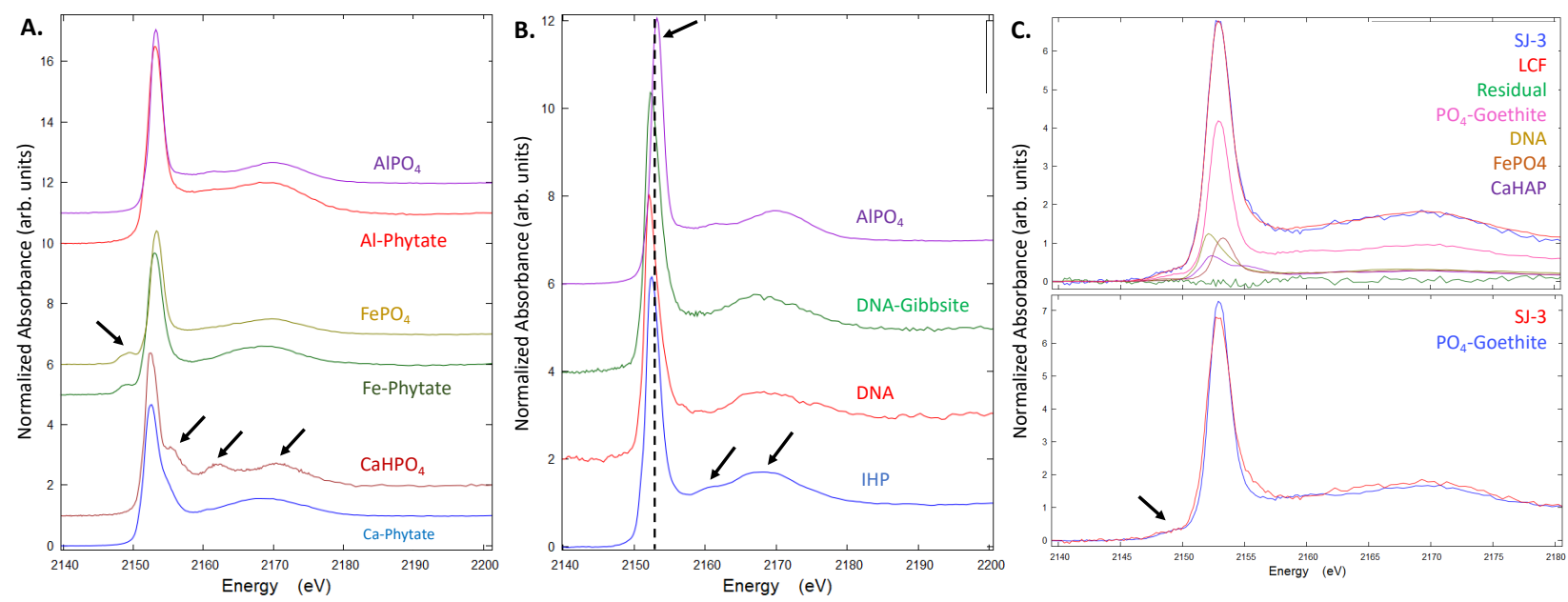

Figure S5. Phosphorus K-edge normalized XANES reference spectra of select inorganic and organic compounds, and a PM sample, with major features indicated with arrows. A. Distinct pre- and post- edge features found with $\mathrm{Al}, \mathrm{Fe}$, and $\mathrm{Ca}$ compounds. $\mathrm{B}$. A representative inorganic compound $\left(\mathrm{AlPO}_{4}\right.$ ) compared with organic species (DNA adsorbed on gibbsite, DNA, and IHP) commonly found in PM samples. The vertical line indicates energy calibration using $\mathrm{NaH}_{2} \mathrm{PO}_{4}$ standard with peak maximum set to $2152.6 \mathrm{eV}$. C. PM sample SJ3 D-1 (1 $\mu \mathrm{m}$ filter) and the linear combination fit with reference spectra, along with an overlay of the major component, $\mathrm{PO}_{4}$ adsorbed to goethite.

Spectra of inorganic orthophosphate bonded to $\mathrm{Fe}$, either in a bulk compound or as an adsorbed species, have distinct pre-edge features, whereas orthophosphate compounds with $\mathrm{Ca}$ or $\mathrm{Al}$, or orthophosphate adsorbed to $\mathrm{Al}$-hydroxide $\left(\mathrm{Al}(\mathrm{OH})_{3}\right.$ as gibbsite), have characteristic post-edge absorption features (Fig. S5). Spectra of Ca hydroxyapatite (CaHAP) and Ca hydroxy phosphate $\left(\mathrm{CaHPO}_{4}\right)$ exhibited a shift of the absorption maximum to slightly lower energy compared to the 
other inorganic $\mathrm{P}$ spectra, along with a characteristic post-edge region where there are three distinct features (Fig. S5A; see also main text Fig. 3). Orthophosphate compounds associated with $\mathrm{Al}$ do not have a pre-edge feature, consist of a narrow white line, and have more rounded, or less pronounced, post-edge features (Fig. S5B). Characteristic spectral features can be diagnostic in PM sample mixtures; for example, PM sample SJ3 D-1 (1 $\mu \mathrm{m}$ filter) displays a prominent pre-edge feature indicative of Fe association (Fig. S5C).

Organic-P compounds were grouped as either monoester IHP (as inositol hexakisphosphate, $\mathrm{Na}$ salt) or diester (as DNA) forms. For DNA, spectra were collected for both the pure compound and as an adsorbed species on gibbsite (Fig. S4). Spectra of organic-P compounds showed a slight shift or broadening, or both, of the absorption maximum to lower energy relative to inorganic phosphate compound spectra (Fig. S5). Previous studies have noted that different forms of organic $\mathrm{P}$ were generally similar in their X-ray absorption spectral signature and thus could not be easily distinguished, although some studies discussed spectral differences. ${ }^{7,8}$ Comparison of the reference spectra show subtle but resolvable differences among different classes of organic P compounds, particularly between P monoester and diester linkages (Fig. S5B), and among P monoester (phytate) bonded to metal cations (Fig. S5A). Monoester (as IHP) and diester (as DNA) display different spectral features in which IHP has two post-edge features and DNA contains only one. In addition, an energy shift of $\sim-0.9 \mathrm{eV}$ for IHP and DNA relative to $\mathrm{AlPO}_{4}$ (which has a similar spectrum as IHP with two post-edge features) assists with differentiating spectra (Fig. S5B).

\section{Solution ${ }^{31}$ P Nuclear Magnetic Resonance (NMR)}

Sample Extraction

Particles were washed from $10 \mu \mathrm{m}$ PTFE filters with ultrapure water. Multiple filters from the same sampling event were combined to achieve adequate particle mass. Particle masses ranging from 30-70 mg were extracted with $5 \mathrm{ml}$ of $0.25 \mathrm{M} \mathrm{NaOH}$ and $0.05 \mathrm{M}$ EDTA solution for $6 \mathrm{~h}$. After extraction, the suspension was centrifuged for $30 \mathrm{~min}$ at 12,200 rpm (Eppendorf Centrifuge 5417C). The supernatant solution was then separated from the residue and filtered with a 0.45 $\mu \mathrm{m}$ syringe filter. To preconcentrate the extract, the filtered solutions were frozen at $-18^{\circ} \mathrm{C}$ and lyophilized for $24 \mathrm{~h}$. Freeze-dried particles were reconstituted to a $0.8-1.0 \mathrm{ml}$ volume with $1 \mathrm{M}$ 
$\mathrm{NaOH}$, from which samples were prepared and immediately used for NMR analysis. Sample residues were acid digested and analyzed for total $\mathrm{P}$ by the methods described above to determine the amount of extracted $\mathrm{P}$.

\section{NMR Data Collection and Analysis}

For NMR data acquisition, $600 \mu 1$ of the extracted, preconcentrated sample were transferred into a $5 \mathrm{~mm}$ NMR tube containing a $\sim 100 \mu \mathrm{l}$ of $\mathrm{D}_{2} \mathrm{O}$ and mixed. ${ }^{31} \mathrm{P}$ NMR data were acquired at $20^{\circ}$ $\mathrm{C}$ on a two-channel Agilent $500 \mathrm{MHz}$ ProPulse500 NMR System with a One NMR Probe and a 96-Sample Robot, which operates at ${ }^{31} \mathrm{P}$ frequency of 202.4 MHz. Spectra were recorded under the following instrumental conditions and parameters: $45^{\circ}$ pulse, $0.68 \mathrm{~s}$ acquisition time, $1 \mathrm{~s}$ pulse delay, and no proton decoupling. The instrument was continuously calibrated with an external standard ( $85 \%$ phosphoric acid) to $0 \mathrm{ppm}$ to avoid instrumental drift. NMR peaks were identified by the combination of visual inspection and comparison to previous literature, as well as comparison with P standards collected in a similar solution matrix as the unknown sample. Standard spectra (phosphonic acid, sodium phosphate, lecithin, DNA, and myo-IHP) were also collected individually and used to verify peak positions and chemical shifts. In addition, peak assignments were further confirmed by spiking previously analyzed samples with orthophosphate and other P standards (Fig. S6). Upon spiking the samples with $\alpha$ - and $\beta$ glycerophosphate, myo-IHP, d-glucose 1-phosphate, and d-glucose 6-phosphate, peaks in the P monoester region were identified and in agreement with previously published chemical shifts. ${ }^{9}$ Peak identifications by Cade-Menun ${ }^{9}$ were used to assign peaks in instances where the specific species was not included in spiking experiments.

Peak assignments and chemical shifts for P compound classes are summarized in Table S3.

Orthophosphate was set at $6 \mathrm{ppm}$. Orthophosphate monoester peaks were identified between 5.75 and $3.15 \mathrm{ppm}$. Orthophosphate diester peaks with chemical shifts between $\sim 2.46$ to $\sim 0.64 \mathrm{ppm}$ were all assignable to phospholipids, lipoteichoic acid, and RNA. Chemical shifts for DNA peaks were identified at -0.29 to -0.65 ppm. ${ }^{9}$ Another diester peak identified at -1.25 to -1.31 is thought to be associated with DNA. After spiking, peaks identified at 5.06 to $5.10 \mathrm{ppm}$ and 4.69 to 4.75 ppm were assignable to $\alpha$ - and $\beta$-glycerophosphate, which are known degradation products of phospholipids. ${ }^{10,11}$ Similarly, peaks at 5.75 to $5.82 \mathrm{ppm}, 4.81$ to $4.88 \mathrm{ppm}, 4.44$ to 
$4.47 \mathrm{ppm}$, and 4.27 to $4.30 \mathrm{ppm}$ became evident as myo-IHP after spiking. Pyrophosphate peaks were identified at -4.45 to $-4.55 \mathrm{ppm}$ and were all associated with close doublet peaks ( -4.08 to -4.12 and -4.18 to $-4.21 \mathrm{ppm}$ ) assignable to the polyphosphate end groups. Other polyphosphate peaks occurred at -9.46 and between -18 to $-19 \mathrm{ppm}$.

NMR spectra were processed (phased and baseline corrected) using the MestReNova 14.0.1 NMR software package. Following spiking experiments, visual identification, and comparison with published standards ${ }^{9}$, peak regions were manually integrated to determine the relative percent of an identified species, and summed according to compound class. Error was determined from replicate runs on LS2-S samples using orthophosphate, orthophosphate monoester, DNA, and pyrophosphate/polyphosphate peaks, and was estimated to be $\leq 2.0 \%$.

Degradation of $\mathrm{P}$ diester compounds into monoester forms is well known and occurs during the initial alkaline extraction, lyophilization, or the ${ }^{31} \mathrm{P}$ NMR experiment, leading to an overestimation of total monoesters and underestimation of diesters. Methodological and NMR experimental advances for environmental samples have allowed for higher resolution spectra and data processing, making it possible to identify and correct for some compound degradation ${ }^{12-15}$. Studies have identified degradation products in the monoester chemical shift region that result from the hydrolysis of diester species. For example, Doolette et al. ${ }^{11}$ found that phospholipids likely degrade into $\alpha$ - and $\beta$ - glycerophosphate, and Makarov et al. ${ }^{16}$ established that RNA hydrolyzes to mononucleotides. In this study, estimated fractions of total diester and monoester compounds were corrected for degradation of diester phospholipid compounds to monoester $\alpha$ and $\beta$ - glycerophosphate. These degradation peaks were identified by standard addition of the known compound to the extracted sample. Peak areas in the unspiked NMR spectrum were manually subtracted from the monoester total and added to the diester total (Fig S6). ${ }^{9}{ }^{14}$ No other peak corrections were done (i.e., mononucleotide peak areas were not integrated and placed into the total diester area) to ensure a conservative correction was used. Sources of error for this correction include inaccurate peak identification and poor quantification of the peak area, both of which would be compounded by signal overlap. Sequential spiking experiments ensured all major monoester peaks were properly identified, including those from phospholipid degradation. These $\alpha$ - and $\beta$-glycerophosphate peaks were prominent and well resolved, making 
quantification possible in all samples even though their chemical shift is near those of other monoesters (i.e., myo-inositol hexakisphosphate; Fig. S6). 


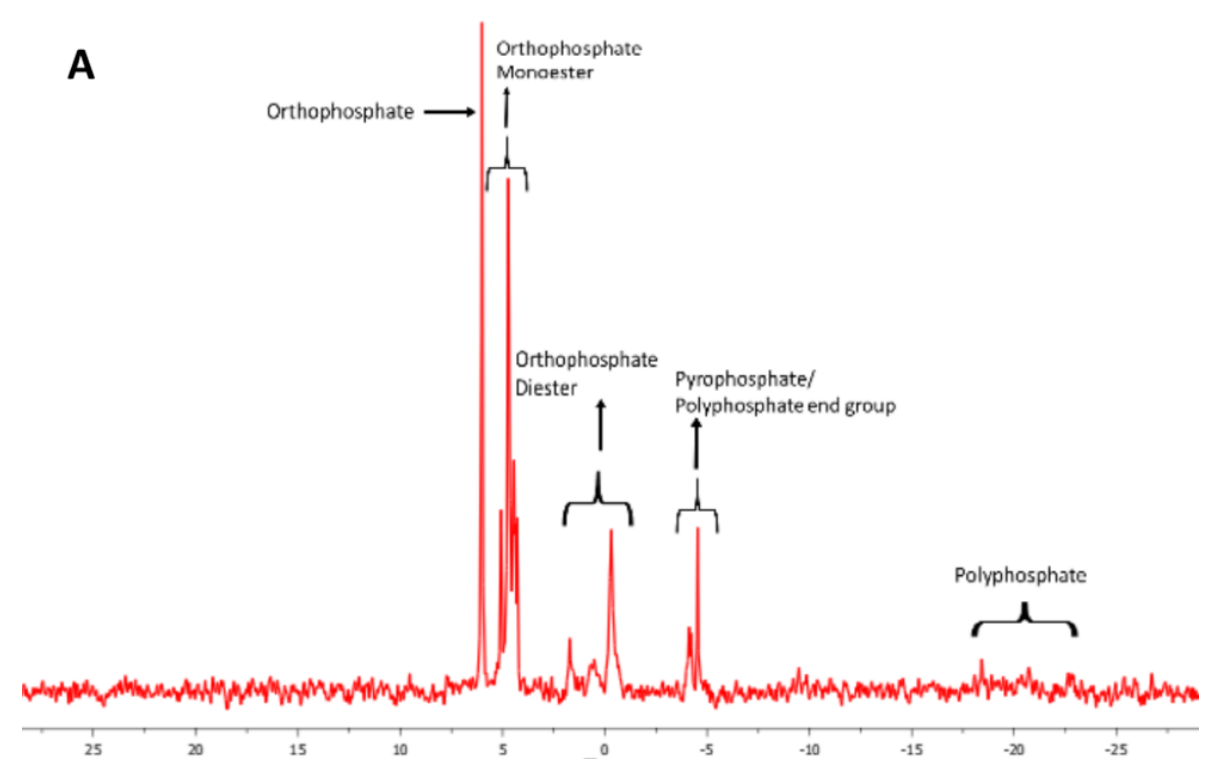

B

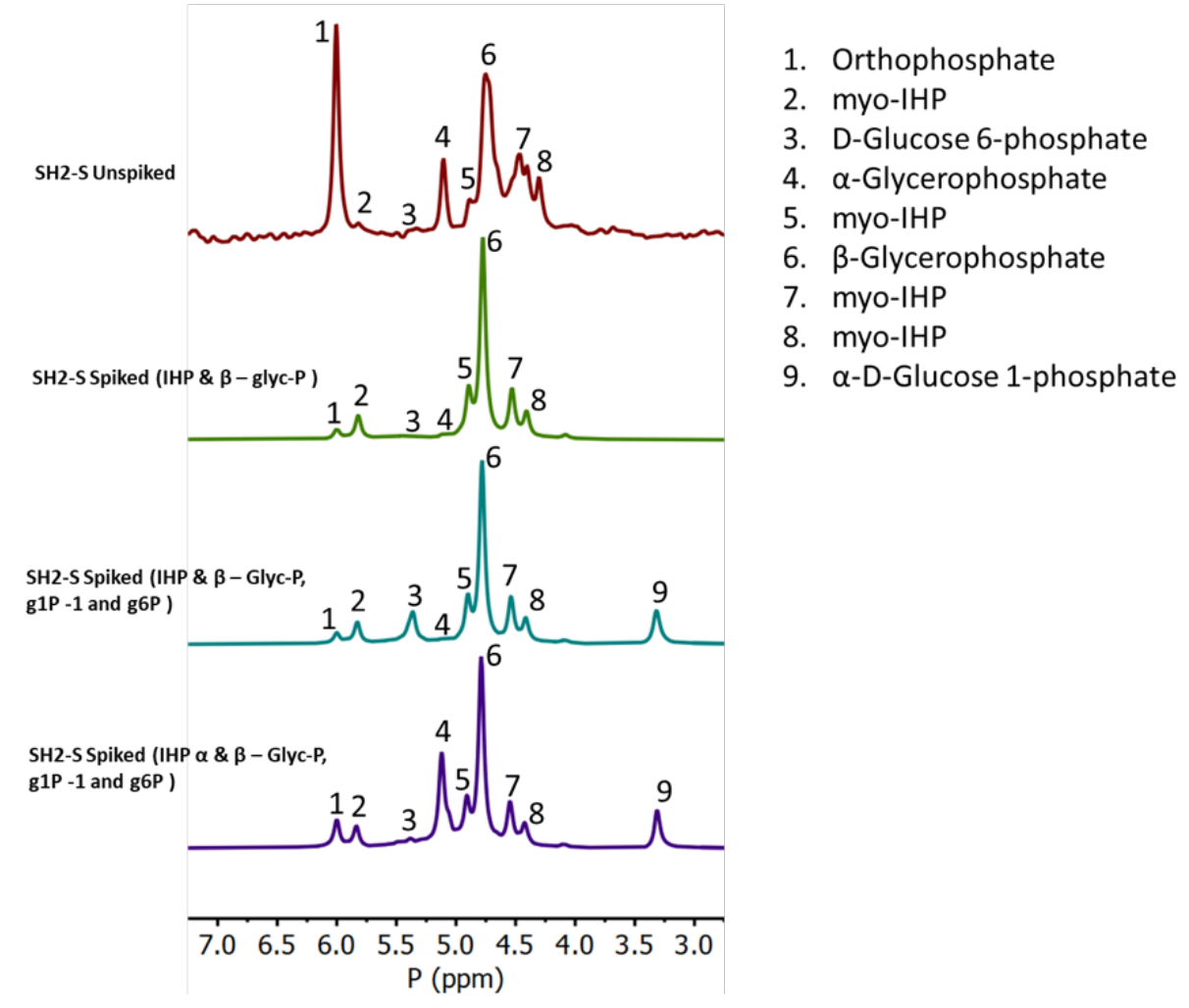

Figure S6. ${ }^{31} \mathrm{P}$ solution NMR spectra of extracted airborne particulate matter (PM) samples. A. Chemical shift regions of major $P$ groups. B. Expanded spectra of chemical shift peaks as labeled in the $\mathrm{P}$ monoester region for CA-SSCZO SH2 PM sample before and after addition of the following standards: myo-IHP (inositol hexakisphosphate), d-glucose 6phosphate, $\alpha$-glycerol 6-phosphate, $\beta$-glycerophosphate, and $\alpha$-d-glucose 1-phosphate. 


\section{Lead Isotopic Analysis}

Lead isotopic analysis followed methods used by Ewing et al. ${ }^{17}$, Christensen et al. ${ }^{18}$, Pierce et al. ${ }^{19}$, and Asher et al. ${ }^{20}$ using a Neptune Plus (Thermo-Fisher) multi-collector ICP source mass spectrometer (MCICPMS) at Lawrence Berkeley National Laboratory (LBNL). Aliquots of solutions were taken from samples dissolved for total element analysis to provide 10-100 ng of $\mathrm{Pb}$ for isotopic analysis. The aliquots were dried down in Teflon vials (Savillex, LLC), brought up again in high purity 0.5 M HBr (Seastar Chemicals), and loaded on new AG1x8 resin (BioRad) using small Teflon columns. The columns were then eluted with $0.5 \mathrm{M} \mathrm{HBr}$ to strip matrix elements, and $\mathrm{Pb}$ collected off the columns with high purity $6 \mathrm{M} \mathrm{HCl}$ (Seastar Chemicals). The separated $\mathrm{Pb}$ was then dried down and taken up again in $1 \mathrm{ml} 0.3 \mathrm{~N} \mathrm{HNO}_{3}$ (high purity, Seastar Chemicals) from which $10 \%$ by volume was taken for $\mathrm{Pb}$ concentration determination using the Neptune Plus MCICPMS. Based on this result, the remaining sample was spiked with natural Tl (NIST SRM997) at $\sim 5 \mathrm{ng}$ Tl per $25 \mathrm{ng}$ sample $\mathrm{Pb}$. The isotopic composition of the $\mathrm{Tl}$ sample $\mathrm{Pb}$ mixture was measured on the Neptune Plus using the monitored ${ }^{230} \mathrm{Tl} /{ }^{205} \mathrm{Tl}$ ratio to correct ${ }^{206} \mathrm{~Pb} /{ }^{207} \mathrm{~Pb}$ and ${ }^{208} \mathrm{~Pb} /{ }^{206} \mathrm{~Pb}$ for instrumental mass fractionation, with normalization to the NIST SRM981 Pb isotopic standard spiked with Tl as above. Sample ${ }^{206} \mathrm{~Pb} /{ }^{207} \mathrm{~Pb}$ and ${ }^{208} \mathrm{~Pb} /{ }^{206} \mathrm{~Pb}$ were also corrected for total chemistry blank, which in most cases was less than $1 \%$ of sample $\mathrm{Pb}$ mass. Analytical uncertainties of the ${ }^{206} \mathrm{~Pb} /{ }^{207} \mathrm{~Pb}$ and ${ }^{208} \mathrm{~Pb} /{ }^{206} \mathrm{~Pb}$ ratios were better than $\pm 0.01 \%$ ( $2 \sigma)$ based on replicates of SRM981.

\section{Calculation of the Fraction of Asian Pb}

The measured ${ }^{206} \mathrm{~Pb} /{ }^{207} \mathrm{~Pb}$ and ${ }^{208} \mathrm{~Pb} /{ }^{206} \mathrm{~Pb}$ of the $\mathrm{PM}$ samples were used to calculate the fraction of Asian $\mathrm{Pb}$ in the sample using a mixing model presented by Ewing et al. ${ }^{17}$ (cf. ${ }^{18-20}$ ). First, the parameter $\Delta 208 \mathrm{~Pb}_{\text {smpl }}$ is calculated, which represents the horizontal displacement of the sample from the California $\mathrm{Pb}$ isotope data array shown in Fig. S5 using Eq. A:

$$
\Delta^{208} \mathrm{~Pb} \mathrm{smpl}=1000\left[\left({ }^{208} \mathrm{~Pb} /{ }^{207} \mathrm{~Pb}\right)_{\mathrm{smpl}}-\left({ }^{208} \mathrm{~Pb} /{ }^{207} \mathrm{~Pb}\right)_{\mathrm{CA}}\right] \quad \text { Eq. A }
$$

where $\left({ }^{208} \mathrm{~Pb} /{ }^{207} \mathrm{~Pb}\right)_{\mathrm{CA}}$ is the ratio the sample would have if its measured ${ }^{206} \mathrm{~Pb} /{ }^{207} \mathrm{~Pb}$ is plotted on the California array ${ }^{17}$ The fraction of Asian $\mathrm{Pb}$ in a sample $\left(\mathrm{F}_{\mathrm{AsianPb}}\right)$ is then calculated from Eq. B: 


$$
\mathrm{F}_{\mathrm{Asia}} \mathrm{Pb}=\Delta^{208} \mathrm{~Pb}_{\text {smpl }} / \Delta^{208} \mathrm{~Pb}_{\text {Asia }} \quad \text { Eq. B }
$$

where $\Delta^{208} \mathrm{~Pb}_{\mathrm{Asia}}$ represents the horizontal offset of Asian sources from the California array; for $100 \%$ Asian $\mathrm{Pb}$ the threshold value is 25 . For samples with $\Delta^{208} \mathrm{~Pb}_{\text {smpl }}$ equal to zero (or less), the sample plots on the California array (or to the left of it) and the fraction of Asian $\mathrm{Pb}$ is taken as zero.

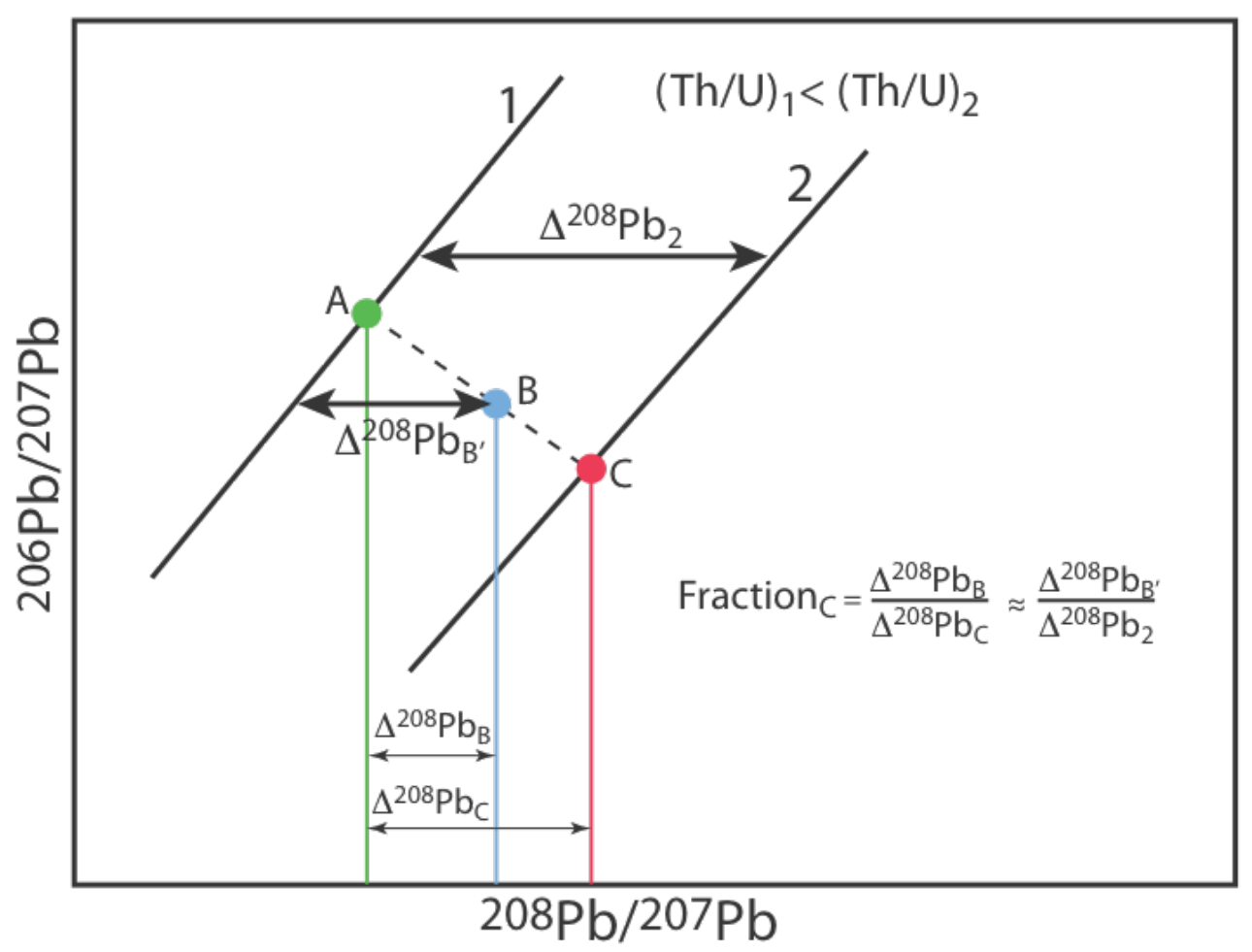

Figure S7. A schematic illustrating the calculation of the fraction of Asian $\mathrm{Pb}$ in a sample. 


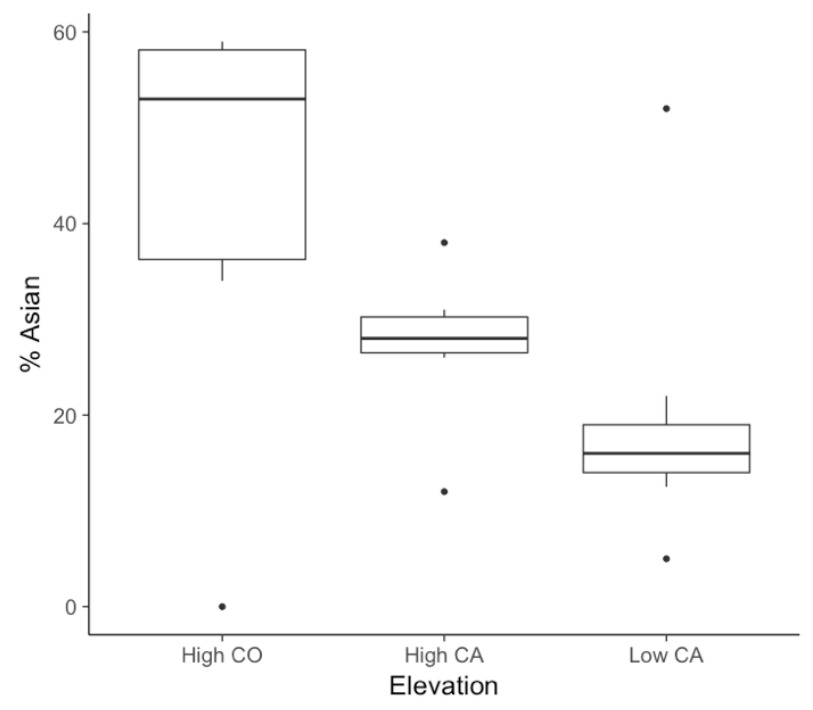

Figure S8. Sample median and distribution of percent Asian $\mathrm{Pb}$ in $\mathrm{PM}$ samples as a function of site for Colorado (CO; two high elevation sites) and California (CA; high and low elevation sites); data from Table S4. The box represents the first and third quartiles $\left(25^{\text {th }}\right.$ and $75^{\text {th }}$ percentiles); whiskers are the highest and lowest values within 1.5 times the inter-quartile range (i.e., the distance between the first and third quartiles); and points outside the box are outliners.

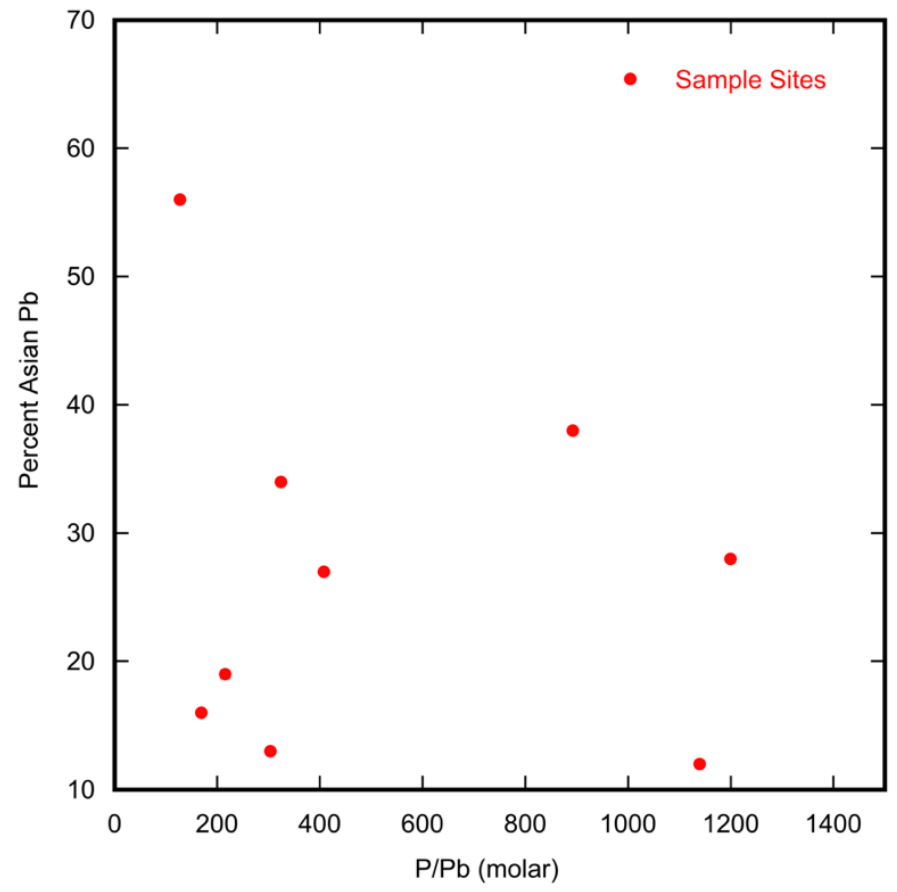

Figure S9. Percent Asian $\mathrm{Pb}$ calculated from $\mathrm{Pb}$ isotopic analyses (Table S4) compared to the molar ratio of total $\mathrm{P} / \mathrm{Pb}$ in digested $\mathrm{PM}$ samples. Each point is an average of measurements ( $n=1$ to 5 ) for each sample site. 
Table S2. Results of linear combination fits of bulk XANES spectra of particulate matter samples.

\begin{tabular}{|c|c|c|c|c|c|c|c|c|c|c|c|c|}
\hline \multirow[b]{2}{*}{ Sample* } & \multirow[b]{2}{*}{$\begin{array}{l}\text { Filter } \\
\text { size } \dagger \\
(\mu \mathrm{m})\end{array}$} & \multicolumn{3}{|c|}{ Organic P (\%) } & \multicolumn{4}{|c|}{ Inorganic P (\%) } & \multicolumn{2}{|c|}{$\begin{array}{c}\text { Inorganic P } \\
\text { (adsorbed) (\%) }\end{array}$} & \multirow[b]{2}{*}{ Total } & \multirow[b]{2}{*}{$\begin{array}{l}\text { R-factor } \\
\left(\times 10^{-4}\right)^{\ddagger}\end{array}$} \\
\hline & & $\begin{array}{l}\text { Mono- } \\
\text { ester } \\
\text { (IHP) }\end{array}$ & $\begin{array}{l}\text { Diester } \\
\text { (DNA) }\end{array}$ & $\begin{array}{l}\text { Diester } \\
\text { adsorbed } \\
\text { (DNA/ } \\
\text { gibbs) }\end{array}$ & Ca HAP & $\mathrm{CaHPO}_{4}$ & $\mathrm{AlPO}_{4}$ & $\mathrm{FePO}_{4}$ & $\begin{array}{r}-\mathrm{PO}_{4} / \\
\text { gibbs }\end{array}$ & $\begin{array}{r}-\mathrm{PO}_{4} / \\
\text { goeth }\end{array}$ & & \\
\hline LS1-D & 10 & 21.0 & & 54.3 & & & 13.3 & & 9.7 & & 98.3 & 2.68 \\
\hline LS2-S & 10 & 33.8 & & 32.6 & & 6.5 & 29.5 & & & & 102.4 & 3.22 \\
\hline LS2-S & 1 & 55.9 & 15.0 & & & & 29.1 & & & & 100.0 & 4.29 \\
\hline PH1-D & 10 & 32.4 & & 59.8 & & & & & 6.9 & & 99.1 & 5.23 \\
\hline $\mathrm{PH} 2-\mathrm{S}$ & 10 & & & 76.9 & 5.9 & & & & 16.8 & & 99.6 & 1.81 \\
\hline PH2-S & 1 & 35.3 & 20.3 & 38.9 & & & & & 5.8 & & 100.3 & 6.31 \\
\hline SH1-D & 10 & 13.9 & 23.2 & 53.5 & & & & & 9.3 & & 99.9 & 6.55 \\
\hline $\mathrm{SH} 2-\mathrm{S}$ & 10 & 22.0 & & 71.0 & & & & & 6.9 & & 99.9 & 6.68 \\
\hline $\mathrm{SH} 2-\mathrm{S}$ & 1 & 59.2 & & 40.4 & & & & & & & 99.6 & 10.3 \\
\hline SH3-D & 10 & 14.5 & & 65.8 & 8.5 & & & & 11.3 & & 100.1 & 10.9 \\
\hline SH3-D & 1 & 27.9 & & 72.0 & & & & & & & 99.9 & 18.4 \\
\hline SJ1-D & 10 & 44.1 & 11.9 & & 27.3 & & 16.7 & & & & 100.0 & 6.41 \\
\hline SJ1-D & 0.2 & 26.4 & & & 57.2 & & & & 18.6 & & 102.2 & 6.45 \\
\hline SJ2-D & 10 & 24.4 & 29.4 & & 33.4 & & & & 12.5 & & 99.7 & 11.2 \\
\hline SJ2-D & 1 & 40.6 & 37.2 & & & 12.3 & & & 10.1 & & 100.2 & 18.5 \\
\hline SJ3-D & 10 & & 30.2 & & 28.3 & & & & 16.4 & 25.4 & 100.3 & 10.0 \\
\hline SJ3-D & 1 & & 18.9 & & 18.6 & & & 15.6 & & 46.2 & 99.3 & 15.1 \\
\hline
\end{tabular}

* D: Dry, S: Snow. Blank cells indicate that the component was not identified in linear combination fit.

$\dagger$ Individual filters with PM measured directly in the beam.

R-factor: statistical goodness-of-fit equal to $\left(\sum{\left.\text { (data-fit })^{2} / \Sigma(\text { data })^{2}\right)}^{2}\right.$ 
Table S3. ${ }^{31} \mathrm{P}$ NMR chemical shift assignments in ppm.

\begin{tabular}{|c|c|c|c|c|c|c|c|c|c|c|c|}
\hline \multirow[t]{2}{*}{ Sample* } & \multirow{2}{*}{$\begin{array}{c}\text { Ortho- } \\
\mathrm{P}_{\dagger}\end{array}$} & \multicolumn{6}{|c|}{ Phosphorus Monoesters } & \multicolumn{2}{|c|}{ Phosphorus Diesters $\$$} & \multirow[t]{2}{*}{ PyroP' } & \multirow[t]{2}{*}{ PolyP ${ }^{\#}$} \\
\hline & & myo-IHP & g6P & P-chol & g1P & a-Glyc & $\beta$-Glyc & DNA & $\begin{array}{l}\text { Other } \\
\text { Diesters }\end{array}$ & & \\
\hline LS2-S & 6.00 & $\begin{array}{l}5.75,4.81 \\
4.44,4.27\end{array}$ & 5.38 & 3.98 & 3.27 & 5.06 & 4.69 & $\begin{array}{l}-0.38 \\
-0.65\end{array}$ & $1.70,0.85$ & -4.45 & $\begin{array}{c}-4.09,-4.18 \\
-18.04,-18.20 \\
-18.32\end{array}$ \\
\hline SH1-D & 6.00 & $\begin{array}{l}5.79,4.85 \\
4.44,4.28\end{array}$ & 5.37 & 4.05 & 3.19 & 5.08 & 4.73 & -0.32 & $\begin{array}{c}1.72,0.66 \\
-1.25\end{array}$ & -4.53 & $\begin{array}{l}-4.12,-4.21 \\
-9.46-18.32 \\
-18.41,-18.50\end{array}$ \\
\hline $\mathrm{SH} 2-\mathrm{S}$ & 6.00 & $\begin{array}{l}5.82,4.88 \\
4.47,4.30\end{array}$ & 5.32 & 4.03 & & 5.10 & 4.75 & $\begin{array}{l}-0.29 \\
-0.53\end{array}$ & $\begin{array}{l}2.46,1.76 \\
0.69,-1.31\end{array}$ & -4.55 & $-4.11,-4.21$ \\
\hline SH3-D & 6.00 & $\begin{array}{l}5.77,4.82 \\
4.45,4.27\end{array}$ & 5.33 & 3.98 & & 5.06 & 4.71 & $\begin{array}{l}-0.32 \\
-0.62\end{array}$ & $1.70,0.71$ & -4.46 & $-4.08,-4.18$ \\
\hline SJ1-D & 6.00 & $\begin{array}{c}5.77,4.84 \\
4.47,4.28\end{array}$ & & & 3.15 & 5.08 & 4.70 & & $0.99,0.64$ & -4.50 & \\
\hline
\end{tabular}

* D: Dry, S: Snow.

† Ortho-P: orthophosphate assigned to $6 \mathrm{ppm}$

¥ myo-IHP: myo-inositol hexakisphosphate; g6p: d-glucose 6-phosphate; P-chol: phosphocholine; g1P: d-glucose 1-phosphate. $\alpha$-Glyc and $\beta$-Glyc: $\alpha-$ and $\beta$ - glycerophosphate originated from the degradation of phospholipids as confirmed by spiking.

$\S$ DNA: deoxyribonucleic acid. Other diesters were PL: phospholipids; LTA: lipoteichoic acid; RNA: ribonucleic acid; and other unknown peaks at

$-1.25,-1.31$, and 2.46 ppm for SH1-D and SH2-S.

g PyroP: pyrophosphates.

\# PolyP: polyphosphates. 
Table S4. Total $\mathrm{Pb}$ concentrations, standard deviations, and isotope ratios of particulate matter samples, and estimated percent sourced from Asia.

\begin{tabular}{|c|c|c|c|c|c|c|c|}
\hline Sample* & Sample ID & $\begin{array}{c}\mathrm{Pb} \\
\left(\mathrm{mg} \mathrm{kg}^{-1}\right)\end{array}$ & ${ }^{206} \mathrm{~Pb} /{ }^{207} \mathrm{~Pb}$ & $\pm 2 \sigma$ & ${ }^{208} \mathrm{~Pb} /{ }^{206} \mathrm{~Pb}$ & $\pm 2 \sigma$ & $\begin{array}{c}\text { Percent } \\
\text { Asian } \\
\text { Source }\end{array}$ \\
\hline LS1-D & LS1016 5 & 45.3 & 1.206227 & 3.1E-05 & 2.458998 & $8.2 \mathrm{E}-05$ & $0 \%$ \\
\hline LS1-D & LS5 & 40.8 & 1.190526 & $1.8 \mathrm{E}-05$ & 2.460943 & 4.7E-05 & $37 \%$ \\
\hline LS2-S & LSO717 3 & 49.0 & 1.193270 & 3.0E-05 & 2.467513 & $6.8 \mathrm{E}-05$ & $54 \%$ \\
\hline LS2-S & LS0717 21 & 41.3 & 1.193749 & 3.0E-05 & 2.469005 & 6.3E-05 & $59 \%$ \\
\hline LS2-S & LS0717 15 & 43.6 & 1.193455 & 3.0E-05 & 2.468631 & $6.0 \mathrm{E}-05$ & $58 \%$ \\
\hline LS2-S & LS0717 10 & 40.5 & 1.192018 & 3.1E-05 & 2.465858 & $6.5 \mathrm{E}-05$ & $52 \%$ \\
\hline LS2-S & LS0717 16 & 44.3 & 1.192371 & 3.0E-05 & 2.467785 & $6.5 \mathrm{E}-05$ & $58.5 \%$ \\
\hline PH1-D & $\mathrm{PH} 5$ & 17 & 1.192554 & 2.6E-05 & 2.461752 & 8.1E-05 & $34 \%$ \\
\hline SH1-D & $\mathrm{SH} 4 \mathrm{~A}$ & 9 & 1.201856 & $1.9 \mathrm{E}-05$ & 2.464025 & 3.4E-05 & $12 \%$ \\
\hline $\mathrm{SH} 2-\mathrm{S}$ & SH-SW5 & 17.8 & 1.175955 & 1.7E-05 & 2.449306 & 5.0E-05 & $38 \%$ \\
\hline SH3-D & SH 9/3/17 \#3 & 15.1 & 1.199895 & $1.4 \mathrm{E}-05$ & 2.467068 & 3.8E-05 & $31 \%$ \\
\hline SH3-D & SH 9/3/17 \#9 & 11.3 & 1.195286 & 1.1E-01 & 2.462015 & 3.4E-05 & $26 \%$ \\
\hline SH3-D & $\mathrm{SH}$ 9/3/17 \#10 & 11.7 & 1.201739 & $1.4 \mathrm{E}-05$ & 2.467807 & 4.2E-05 & $28 \%$ \\
\hline SH3-D & SH 9/3/17 \#11 & 11.8 & 1.199707 & $1.2 \mathrm{E}-05$ & 2.466107 & 2.6E-05 & $28 \%$ \\
\hline SJ1-D & SJER & 42.6 & 1.204379 & 3.7E-05 & 2.467054 & $1.42 \mathrm{E}-04$ & $16 \%$ \\
\hline SJ2-S & 10SJ0717 3 & 26.1 & 1.194487 & $2.9 \mathrm{E}-05$ & 2.460384 & $5.4 \mathrm{E}-05$ & $22 \%$ \\
\hline SJ2-S & 10SJ0717 4a & 25.5 & 1.194937 & $2.9 \mathrm{E}-05$ & 2.458881 & 5.5E-05 & $14 \%$ \\
\hline SJ2-S & 10SJ0717 5 & 24.2 & 1.192785 & 3.0E-05 & 2.458207 & 5.4E-05 & $19 \%$ \\
\hline SJ2-S & 10SJ0717 7 & 33.0 & 1.180319 & $2.9 \mathrm{E}-05$ & 2.456263 & 5.6E-05 & $52 \%$ \\
\hline SJ3-D & 10SJO817 1 & 25.4 & 1.196959 & 3.0E-05 & 2.460900 & $6.4 \mathrm{E}-05$ & $16 \%$ \\
\hline SJ3-D & 10SJO817 \#4b & 22.5 & 1.204906 & 3.1E-05 & 2.467791 & 5.7E-05 & $17 \%$ \\
\hline SJ3-D & 10SJO817 \#6 & 17.6 & 1.202942 & 1.4E-05 & 2.464961 & 4.0E-05 & $12.5 \%$ \\
\hline SJ3-D & 10SJO817 \#7 & 21.6 & 1.204707 & $1.5 \mathrm{E}-05$ & 2.464490 & 4.1E-05 & $5 \%$ \\
\hline
\end{tabular}

${ }^{*}$ Individual filter samples were measured for a given sample location and sampling interval; D: Dry, S: Snow 


\section{SI References}

(1) Aciego, S. M.; Riebe, C. S.; Hart, S. C.; Blakowski, M. A.; Carey, C. J.; Aarons, S. M.;

Dove, N. C.; Botthoff, J. K.; Sims, K. W. W.; Aronson, E. L., Dust outpaces bedrock in nutrient supply to montane forest ecosystems. Nature Comm. 2017, 8, 10.

(2) He, Z.; Honeycutt, C. W.; Zhang, T.; Bertsch, P. M., Preparation and FT-IR characterization of metal phytate compounds. J. Environ. Qual. 2006, 35, (4), 1319-1328.

(3) Schwertmann, U.; Cornell, R. M., Iron Oxides in the Laboratory: Preparation and Characterization, Second Edition. Wiley-VCH: 2000.

(4) Webb, S. M., SIXpack: a graphical user interface for XAS analysis using IFEFFIT. Phys. Scr. 2005, T115, 1011-1014.

(5) Ravel, B.; Newville, M., "ATHENA, ARTEMIS, HEPHAESTUS: Data analysis for Xray absorption spectroscopy using IFEFFIT" J. Synch. Rad. 2005, 537-541.

(6) Khare, N.; Hesterberg, D.; Martin, J. D., XANES investigation of phosphate sorption in single and binary systems of iron and aluminum oxide minerals. Environ. Sci. Technol. 2005, 39, (7), 2152-2160.

(7) Prietzel, J.; Harrington, G.; Hausler, W.; Heister, K.; Werner, F.; Klysubun, W., Reference spectra of important adsorbed organic and inorganic phosphate binding forms for soil P speciation using synchrotron-based K-edge XANES spectroscopy. J. Synch. Rad. 2016, 23, (2), 532-544.

(8) Hesterberg, D., Chapter 11 - Macroscale Chemical Properties and X-Ray Absorption Spectroscopy of Soil Phosphorus. In Developments in Soil Science, Balwant, S.; Markus, G., Eds. Elsevier: 2010; Vol. Volume 34, pp 313-356.

(9) Cade-Menun, B. J., Improved peak identification in P-31-NMR spectra of environmental samples with a standardized method and peak library. Geoderma 2015, 257, 102-114.

(10) Turner, B. L.; Mahieu, N.; Condron, L. M., Phosphorus-31 nuclear magnetic resonance spectral assignments of phosphorus compounds in soil NaOH-EDTA extracts. Soil Sci. Soc. Am. J. 2003, 67, (2), 497-510.

(11) Doolette, A. L.; Smernik, R. J.; Dougherty, W. J., Spiking Improved Solution Phosphorus-31 Nuclear Magnetic Resonance Identification of Soil Phosphorus Compounds. Soil Sci. Soc. Am. J. 2009, 73, (3), 919-927. 
(12) Cade-Menun, B. J.; Carter, M. R.; James, D. C.; Liu, C. W., Phosphorus Forms and Chemistry in the Soil Profile under Long-Term Conservation Tillage: A Phosphorus-31 Nuclear Magnetic Resonance Study. J. Environ. Qual. 2010, 39, (5), 1647-1656.

(13) Liu, J.; Yang, J. J.; Liang, X. Q.; Zhao, Y.; Cade-Menun, B. J.; Hu, Y. F., Molecular Speciation of Phosphorus Present in Readily Dispersible Colloids from Agricultural Soils. Soil Sci. Soc. Am. J. 2014, 78, (1), 47-53.

(14) Schneider, K. D.; Cade-Menun, B. J.; Lynch, D. H.; Voroney, R. P., Soil Phosphorus Forms from Organic and Conventional Forage Fields. Soil Sci. Soc. Am. J. 2016, 80, (2), 328340.

(15) Recena, R.; Cade-Menun, B. J.; Delgado, A., Organic Phosphorus Forms in Agricultural Soils under Mediterranean Climate. Soil Sci. Soc. Am. J. 2018, 82, (4), 783-795.

(16) Makarov, M. I.; Haumaier, L.; Zech, W., Nature of soil organic phosphorus: an assessment of peak assignments in the diester region of P-31 NMR spectra. Soil Biol. Biochem. 2002, 34, (10), 1467-1477.

(17) Ewing, S. A.; Christensen, J. N.; Brown, S. T.; Vancuren, R. A.; Cliff, S. S.; Depaolo, D. $\mathrm{J} ., \mathrm{Pb}$ Isotopes as an Indicator of the Asian Contribution to Particulate Air Pollution in Urban California. Environ. Sci. Technol. 2010, 44, (23), 8911-8916.

(18) Christensen, J. N.; Weiss-Penzias, P.; Fine, R.; McDade, C. E.; Trzepla, K.; Brown, S. T.; Gustin, M. S., Unraveling the sources of ground level ozone in the Intermountain Western United States using Pb isotopes. Sci. Total Environ. 2015, 530, 519-525.

(19) Pierce, A. M.; Gustin, M. S.; Christensen, J. N.; Loria-Salazar, S. M., Use of multiple tools including lead isotopes to decipher sources of ozone and reactive mercury to urban and rural locations in Nevada, USA. Sci. Total Environ. 2018, 615, 1411-1427.

(20) Asher, E. C.; Christensen, J. N.; Post, A.; Perry, K.; Cliff, S. S.; Zhao, Y. J.; Trousdell, J.; Faloona, I., The Transport of Asian Dust and Combustion Aerosols and Associated Ozone to North America as Observed From a Mountaintop Monitoring Site in the California Coast Range. J. Geophys. Res., Atmos. 2018, 123, (10), 5667-5680. 